\title{
Thrombospondin-1 Is Required for Normal Murine Pulmonary Homeostasis and Its Absence Causes Pneumonia
}

\author{
Jack Lawler, Mary Sunday, Valérie Thibert, Mark Duquette, Elizabeth L. George, Helen Rayburn, and Richard O. Hynes \\ Departments of Pathology, Beth Israel Deaconess Medical Center, Brigham and Women's Hospital, Children's Hospital and Harvard \\ Medical School, Boston, Massachusetts 02215; and the Howard Hughes Medical Institute, Center for Cancer Research and Department of \\ Biology, Massachusetts Institute of Technology, Cambridge, Massachusetts 02139
}

\begin{abstract}
The thrombospondins are a family of extracellular calciumbinding proteins that modulate cellular phenotype. Thrombospondin-1 (TSP-1) reportedly regulates cellular attachment, proliferation, migration, and differentiation in vitro. To explore its function in vivo, we have disrupted the TSP-1 gene by homologous recombination in the mouse genome. Platelets from these mice are completely deficient in TSP-1 protein; however, thrombin-induced platelet aggregation is not diminished. TSP-1-deficient mice display a mild and variable lordotic curvature of the spine that is apparent from birth. These mice also display an increase in the number of circulating white blood cells, with monocytes and eosinophils having the largest percent increases. The brain, heart, kidney, spleen, stomach, intestines, aorta, and liver of TSP-1-deficient mice showed no major abnormalities. However, consistent with high levels of expression of TSP-1 in lung, we observe abnormalities in the lungs of mice that lack the protein. Although normal at birth, histopathological analysis of lungs from 4-wk-old TSP-1-deficient mice reveals extensive acute and organizing pneumonia, with neutrophils and macrophages. The macrophages stain for hemosiderin, indicating that diffuse alveolar hemorrhage is occurring. At later times, the number of neutrophils decreases and a striking increase in the number of hemosiderin-containing macrophages is observed associated with multiple-lineage epithelial hyperplasia and the deposition of collagen and elastin. A thickening and ruffling of the epithelium of the airways results from increasing cell proliferation in TSP-1-deficient mice. These results indicate that TSP-1 is involved in normal lung homeostasis. (J. Clin. Invest. 1998. 101:982-992.) Key words: thrombospondin • lung • pneumonia • extracellular matrix • gene knockout
\end{abstract}

\section{Introduction}

Thrombospondin-1 (TSP-1) ${ }^{1}$ is an extracellular calcium-binding protein that is a member of a family of five related proteins

\footnotetext{
Address correspondence to Dr. Jack Lawler, Department of Pathology, Beth Israel Deaconess Medical Center, Research North, Room 270C, 99 Brookline Ave., Boston, MA 02215. Phone: 617-667-1694; FAX: 617-667-3591; E-mail: lawler@mbcrr.harvard.edu

Received for publication 10 September 1997 and accepted in revised form 18 December 1997.
}

J. Clin. Invest.

(C) The American Society for Clinical Investigation, Inc. 0021-9738/98/03/0982/11 \$2.00

Volume 101, Number 5, March 1998, 982-992

http://www.jci.org
$(1,2)$. In addition to calcium, TSP-1 binds heparan sulfate proteoglycans, the $\alpha v \beta 3, \alpha 3 \beta 1, \alpha 4 \beta 1$, and $\alpha 5 \beta 1$ integrins, the integrin-associated protein, and CD36 on the cell surface (3-8). TSP-1 can also bind other extracellular proteins including plasminogen, fibrinogen, fibronectin, and urokinase (9-11). Also, it has the ability to bind and activate TGF- $\beta$ (12). Through these interactions TSP-1 modulates cellular migration, differentiation, and proliferation. The specific effect of TSP-1 on cellular phenotype depends on the target cell type and the repertoire of cell surface proteins that are expressed by that cell. For example, TSP-1 promotes proliferation of vascular smooth muscle cells and inhibits proliferation of endothelial cells (1316). TSP-1 also exhibits variable effects on cellular adhesion. It supports attachment and spreading of skeletal myoblasts; however, like SPARC and tenascin, TSP-1 expresses antiadhesive activity toward endothelial cells $(17,18)$. Intact TSP-1 and peptides derived from the heparin-binding domain disrupt focal contacts that are formed by endothelial cells on fibronectincoating substrates (18).

The members of the thrombospondin gene family are expressed widely during murine development (19-22). TSP-1 is expressed at high levels in developing heart, lung, liver, brain, kidney, bone, and skeletal muscle. TSP-1 mRNA is observed in the developing cartilage of the mouse embryo after day 13 and in the bone after day 16 (20). TSP-1 is expressed by mesenchymal cells as they condense to form ribs and vertebrae. The highest level of TSP-1 expression is associated with osteoblasts. Chondrocytes appear to contain low levels of TSP-1 mRNA $(20,23)$. Consistent with this low level of expression, immunocytochemistry fails to detect TSP-1 protein in most chondrocytes (19). However, a rim of TSP-1 immunoreactivity is observed where chondroid elements merge with adjacent stroma. In addition, TSP-1 has been purified from articular cartilage (24).

TSP-1 mRNA expression in the developing mouse lung begins at day 14 and persists to fetal day 18 (20). In the lung, it is expressed in the columnar epithelium of the bronchi. TSP-1 protein is specifically localized to the basement membrane of the forming bronchi in the developing mouse embryo (21). Basement membrane staining within the lung is also detected in adult mouse and human tissue $(21,25)$. In addition, TSP-1 is synthesized and secreted by alveolar macrophages and type II cells (reference 26 and Yehualaeshet, T., J.E. Murphy-Ullrich, R. Silverstein, J. Green-Johnson, S. Mai, and N. Khalil, manuscript submitted for publication). TSP-2 and -3 mRNA are also present in the lung; however, their temporal and spatial patterns of expression are distinct from that of TSP-1 (20).

1. Abbreviations used in this paper: CGRP, calcitonin gene-related peptide; ES cells, embryonic stem cells; neo, neomycin; SP, surfactant protein; TSP, thrombospondin. 
To evaluate the in vivo functions of TSP-1, we have produced TSP-1-deficient mice by homologous recombination in embryonic stem (ES) cells. Most of these mice are viable and exhibit subtle abnormalities in development. However, the adult mice exhibit increased inflammatory cell infiltrates and epithelial cell hyperplasia in the lungs. The presence of hemosiderin-laden macrophages indicates that diffuse alveolar hemorrhage occurs in the lungs of TSP-1-deficient mice, probably secondary to severe pneumonia. These mice provide a unique model for the evaluation of the role of TSP-1 in physiological processes.

\section{Methods}

Construction of the targeting vector. Isolation and characterization of mouse TSP-1 genomic clones has been described previously (27). The region of genomic DNA that contains exon 2, intron 3, and exon 3 was removed and replaced with the neomycin (neo) resistance gene driven by the PGK-promoter (28; see Fig. 1). A greater number of neomycin-resistant colonies and homologous recombination events was obtained with the neomycin-resistance cassette in the opposite orientation to the TSP- 1 gene. The construct included $\sim 1.2 \mathrm{~kb}$ of sequence upstream of exon 2 and $\sim 6.0 \mathrm{~kb}$ of sequence downstream of exon 3. The herpes simplex thymidine kinase (HSV-tk) gene was placed at the $3^{\prime}$ end of the targeting construct as a second selectable marker (29). The presence of the neomycin-resistance gene introduces an EcoRI and a StuI site, which resulted in shortened restriction fragments on Southern blots (see Fig. 1).

Transfection and selection of ES cells. D3 ES cells (30) (kindly provided by Dr. Janet Rossant, Toronto, Canada) were cultured in DME (DME high glucose) supplemented with $26 \mathrm{mM}$ Hepes buffer (pH 7.5), $14 \mathrm{mM}$ sodium bicarbonate, nonessential amino acids, $0.1 \mathrm{mM}$ $\beta$-mercaptoethanol, $10 \mathrm{ng} / \mathrm{ml}$ of leukemia inhibitory factor, and $15 \%$ fetal calf serum (JRH Biosciences, Lenexa, KS). The ES cells were cultured on $\gamma$-irradiated embryonic fibroblasts and were electroporated as described previously (28).

Analysis of genomic DNA. ES cell DNA and tail DNA were prepared by proteinase $\mathrm{K}$ digestion at 37 or $55^{\circ} \mathrm{C}$, respectively, followed by isopropanol precipitation (31). This DNA was used for PCR with reverse TSP-1 primer (5'-GAGTTTGCTTGTGGTGAACGCTCAG) and a forward neo primer (5'-TGCTGTCCATCTGCACGAGACTAG) for the mutant allele or a forward TSP-1 primer (5'-AGGGCTATGTGGAATTAATATCGG) for the wild-type allele. The wild-type and mutant alleles yield PCR products of 700 and $400 \mathrm{bp}$, respectively. PCR was performed as described previously (32).

For Southern blot analysis, the DNA was extracted twice with an equal volume of phenol/chloroform $(1: 1 \mathrm{vol} / \mathrm{vol})$ and once with an equal volume of chloroform and was precipitated with $0.1 \mathrm{M} \mathrm{Na}$-acetate and $2.5 \times$ volume ethanol. Southern blots were prepared and probed according to Maniatis et al. (33).

RNase protection analysis. RNA was isolated from adult (7-29wk-old) brain, heart, lung, and kidney and from 2.5-d-old mice using the Totally RNA kit (Ambion, Inc., Austin, TX). Organs from six mice of each genotype were pooled for each preparation of RNA. RNA probes were prepared for mouse TSP-1, $-2,-3$, and -4 , and actin using the Maxiscript kit (Ambion, Inc.). The resulting signal was quantitated using a PhosphorImager (Molecular Dynamics, Sunnyvale, CA). The ratio of TSP-2, -3, and -4 RNA in TSP-1-deficient mice as compared with wild-type mice was divided by the equivalent ratio for actin RNA to control for variations in the quantity of initial RNA in the RNase protection assay.

Histology. Tissues were fixed in $4 \%$ paraformaldehyde prepared in PBS as described previously (19). With the exception of the lung, adult organs were dissected out of the mice and placed in fixative overnight at $4^{\circ} \mathrm{C}$. For lung preparations, the mice were killed with ether and dissected to expose the trachea. An incision was made in the abdominal wall below the diaphragm to reduce pressure and allow the lungs to expand. A section of tubing was inserted into the trachea and fixative was allowed to fill the air spaces of the lung for $1 \mathrm{~h}$ at a hydrostatic pressure of $23 \mathrm{~cm}$. After $1 \mathrm{~h}$, the lungs were removed and placed in fixative overnight at $4^{\circ} \mathrm{C}$. Bone and cartilage in intact 1-d-old mice were visualized using alizarin red and Alcian blue stains (34). Brain capillaries were visualized with Griffonia (Bandeiraea) simplicifolia lectin I-isolectin B4 (Vector Laboratories, Burlingame, CA; 1:200 dilution) using 10- $\mu \mathrm{m}$ sections of Metha Carnoys-fixed tissue. Immunocytochemistry to identify Clara cells was performed with the CC10 antiserum (generous gift of Dr. G. Singh, University of Pittsburgh and VA Medical Center, Pittsburgh, PA). Antiserum to prosurfactant protein-C (pro-SP-C, R68514, generous gift of Dr. J. Whitsett, Children's Hospital Medical Center, Cincinnati, $\mathrm{OH}$ ) was used as a marker of type II cells (35). Rabbit polyclonal anti-rat calcitonin gene-related peptide (CGRP) antiserum (Peninsula Laboratories, Belmont, CA) was used as a marker for neuroendocrine cells. An antidesmin antibody (Dako Corp., Carpinteria, CA) was used for immunocytochemical detection of smooth muscle cells. Immunoperoxidase analysis was carried out with the standard $\mathrm{ABC}$ kit (Vector Laboratories) as described previously $(36,37)$.

Blood cell counts. Blood was drawn from 3-5-mo-old mice by periorbital insertion of a heparinized capillary tube $\sim 1.5 \mathrm{~cm}$ in length. Mice were anesthetized with $2.5 \%$ avertin. The blood was drawn into tubes containing $50 \mu \mathrm{l}$ of acid-citrate dextrose. Whole blood was diluted 1:1,000 in $20 \mathrm{ml}$ of isotonic saline, five drops of Zapaglobin were added, and white blood cells were counted (Coulter Corp., Miami, FL). Subpopulations were quantitated by a trained hematology technician using standard techniques. Platelets were isolated by differential centrifugation and washed in $\mathrm{pH} 6.5$ buffer containing $0.102 \mathrm{M} \mathrm{NaCl}, 3.9 \mathrm{mM} \mathrm{K}_{2} \mathrm{HPO}_{4}, 3.9 \mathrm{mM} \mathrm{Na}_{2} \mathrm{HPO}_{4}, 22 \mathrm{mM}$ $\mathrm{Na}_{2} \mathrm{HPO}_{4}$, and $5.5 \mathrm{mM}$ glucose. The platelets were resuspended in 15 $\mathrm{mM}$ Tris- $\mathrm{HCl}$ ( $\mathrm{pH} 7.6), 0.14 \mathrm{M} \mathrm{NaCl}$, and $5 \mathrm{mM}$ glucose and mixed with a one-half volume of sample buffer containing $0.25 \mathrm{M}$ Tris- $\mathrm{HCl}$ ( $\mathrm{pH} 7.5$ ), $5 \%$ SDS, $1.25 \mathrm{M}$ sucrose with or without $0.1 \mathrm{M}$ dithiothreitol (38). Samples were electrophoresed on $3.5-15 \%$ gradient gels and stained with Coomassie brilliant blue or transferred to Immobilon-P as described previously (39). TSP-1 was detected using a rabbit polyclonal anti-human platelet thrombospondin antibody designated R1.

Bleeding time and platelet aggregation. The bleeding time was performed as described by Dejana et al. (40). TSP-1-deficient and wild-type mice (15-22 g) were maintained in a restrainer and a distal 5 -mm segment of tail was severed with a razor blade. The tail was immediately immersed in a beaker containing a $0.9 \% \mathrm{NaCl}$ solution at $37^{\circ} \mathrm{C}$, with the tip of the tail $5 \mathrm{~cm}$ below the body. Immersion defined the starting point, and bleeding time was defined as the time required for the blood stream to stop completely.

For aggregation studies, mouse platelets were isolated and washed once as described above except that the final resuspension buffer contained $1 \mathrm{mM} \mathrm{CaCl}_{2}$. The platelet counts were determined and the volumes were adjusted to give an equivalent number of platelets per milliliter. $250-\mu \mathrm{l}$ samples were stirred at $1,000 \mathrm{rpm}$ in an aggregometer at $37^{\circ} \mathrm{C}$ and $0.25-1 \mu \mathrm{l}$ of human thrombin $(100 \mathrm{U} / \mathrm{ml}$; Sigma Chemical Co., St. Louis, MO) was added. The change in optical density was monitored for 3-4 min.

\section{Results}

Production of TSP-1-deficient mice. 240 ES cell clones were isolated by selection with G418 and gancyclovir. Southern blot analysis indicated that seven of these clones have a disruption of the TSP-1 gene (Fig. 1). Five of these clones were used to inject blastocysts derived from C57BL/6 mice. 18 chimeric males (50-95\% chimerism based on coat color) were bred to C57BL/6 females and germline transmission of the targeted allele was observed for all five ES cell clones. Southern blotting of DNA digested with EcoRI or StuI and probed with a TSP-1 or a neo- 


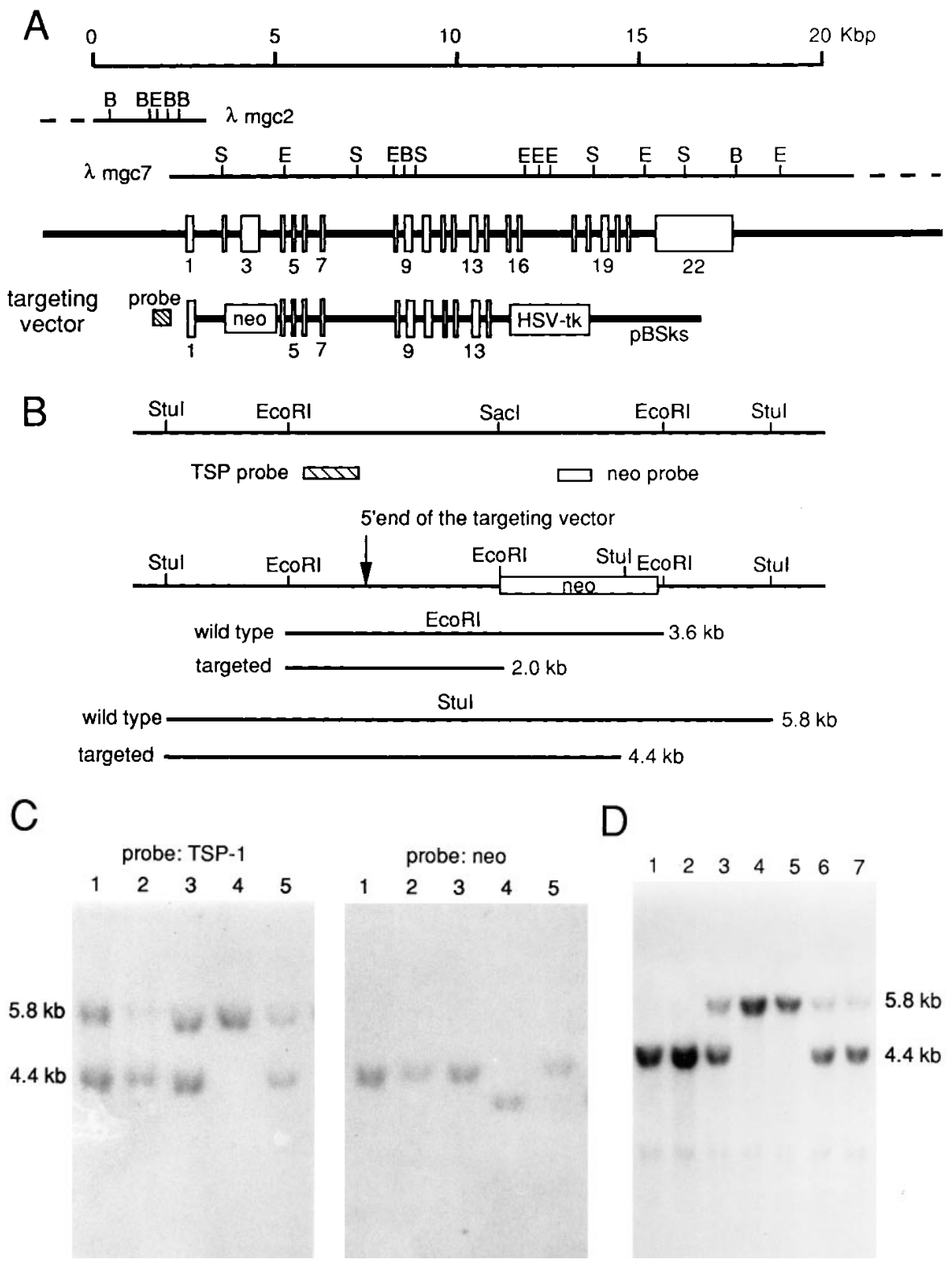

Figure 1. Targeted disruption of the TSP-1 gene. $(A)$ Restriction map and gene structure of the TSP- 1 gene. The TSP- 1 gene is contained on two genomic clones $(\lambda$ mgc 2 and $\lambda$ mgc7). Restriction sites are shown for BamHI $(B)$, EcoRI $(E)$, and SacI $(S)$. DNA from both clones has been used to construct a targeting vector that replaces exons 2 and 3 and introns 2 and 3 with the pgk neo gene. The herpes simplex virus thymidine kinase ( $H S V$ - $t k)$ gene is included as a second selectable marker. $(B)$ Restriction map of the wild-type and targeted alleles. Introduction of the pgk neo gene results in a shortening of an EcoRI and a StuI restriction fragment. (C) Southern blot of genomic DNA from five selected ES cell lines. Genomic DNA was digested with StuI and hybridized with a probe for TSP-1 or pgk neo. In cell lines where the TSP-1 gene has been disrupted (lanes 1-3 and 5), the 4.4-kb StuI fragment hybridizes with both probes. For comparison, a cell line in which the TSP-1 gene is not disrupted (lane 4 ) does not produce the 4.4-kb StuI fragment. $(D)$ Southern blot analysis of genomic DNA from the offspring of a heterozygous cross. DNA was digested with StuI and probed with the TSP-1 probe. The offspring are homozygous for the wild-type allele (lanes 4 and 5), heterozygous (lanes 3, 6, and 7), or homozygous for the targeted allele (lanes 1 and 2). mycin probe produced the predicted results for targeted disruption of the TSP-1 gene. In addition, PCR with primers located in the TSP-1 gene and the neomycin-resistance gene produced a product of the predicted size (data not shown). Since D3 ES cells were derived from 129Sv blastocysts, chimeric males were also bred to $129 \mathrm{~Sv}$ females to establish the mutation on a homogeneous genetic background. Southern blot analysis of the offspring of heterozygous crosses revealed the presence of all possible genotypes (Fig. 1). The homozygous group has fewer animals than expected in both the mixed $129 \mathrm{~Sv} / \mathrm{C} 57 \mathrm{BL} / 6$ and the homogeneous $129 \mathrm{~Sv}$ backgrounds (total: $145+/+, 265+/-$, and $111-/-)$. Taken together, $\chi^{2}$ analysis indicated that there is a $96 \%$ chance that this distribution is abnormal and there is a decrease in the viability of the TSP1-deficient mice. Colonies of wild-type and homozygous TSP1-deficient mice in the 129Sv background were established by breeding the two genotypes from the heterozygous crosses.
The homozygous matings produce significantly $(P \leq 0.005)$ fewer cumulative litters per breeding pair $(3.4 \pm 1.7, n=23)$ than the wild-type matings $(7.2 \pm 2.5, n=14)$. Mating pairs were killed if they did not produce another litter in 3 mo and these values do not include matings in either colony that did not produce any litters. At weaning, the homozygous litters produced significantly $(P \leq 0.01)$ fewer offspring per litter $(4.8 \pm 1.9, n=26)$ than the wild-type colony $(6.2 \pm 2.2, n=24)$.

To establish that the TSP-1 gene expression was disrupted, an RNase protection assay was performed on tissues from wild-type and TSP-1-deficient mice with a probe for exon 3. In the wild-type mice, varying levels of TSP-1 message were observed (Fig. 2). The highest level of expression was observed in the lung of adult mice and in the 2.5-d-old pup. Intermediate levels of expression of TSP-1 are observed in the heart and kidney, and the brain and liver express low levels. The predicted protected fragment was not observed in RNA from any 


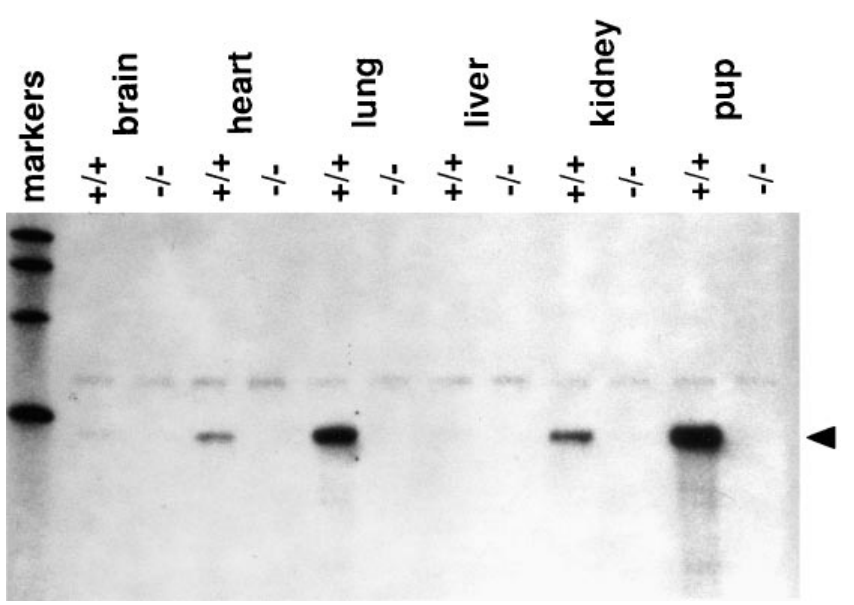

Figure 2. RNase protection assay for TSP-1 mRNA. RNA from adult brain (second and third lanes), heart (fourth and fifth lanes), lung (sixth and seventh lanes), liver (eighth and ninth lanes), and kidney (tenth and eleventh lanes), and 2.5-d-old mouse (twelfth and thirteenth lanes) was isolated from wild-type (second, fourth, sixth, eighth, tenth, and twelfth lanes) or TSP-1-deficient mice (third, fifth, seventh, ninth, eleventh, thirteenth lanes). The gel also includes an RNA ladder (first lane). mRNA protected bands in the brain and liver samples are readily detectable on longer exposures.

of the tissues from the TSP-1-deficient mice. An abnormal TSP-1 transcript is detected when a probe for sequences that were not deleted is used.

To establish that the TSP-1 protein is not produced, we isolated blood platelets from the various genotypes. Electrophoresis of nonreduced platelet proteins from wild-type mice revealed the presence of the 450,000-D TSP-1 trimer (Fig. 3). In the presence of reducing agents, the TSP-1 polypeptides migrate at 185,000 and $160,000 \mathrm{D}$ (data not shown). A variable amount of the $160,000-\mathrm{D}$ peptide is observed in preparations of purified human platelet TSP-1. This peptide is produced by proteolytic removal of the $25,000-\mathrm{D}, \mathrm{NH}_{2}$-terminal, heparinbinding domain. This proteolysis appears to be more extensive in the mouse. Since the intact trimeric protein can contain 0-3 degraded subunits, it electrophoreses as multiple bands with molecular weights of 375,000-450,000 (Fig. 3). Platelets from mice that are homozygous for the targeted allele do not con-
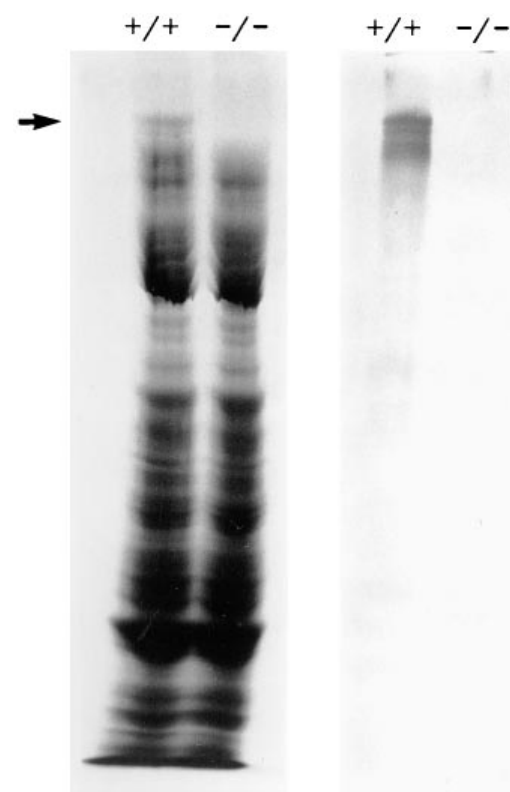

Figure 3. SDS-PAGE of mouse platelets. Washed platelets from a wild-type $(+/+)$ and a TSP-1-deficient mouse $(-/-)$ were electrophoresed in the absence of reducing agent. Parallel samples were stained with Coomassie blue (left) or transferred to Immobilon $P$ and probed with a polyclonal anti-TSP-1 antibody. The arrow indicates the position of the intact TSP-1 band.

tain TSP-1 protein (Fig. 3). Platelets from heterozygous mice appear to have approximately one-half the quantity of TSP-1 as wild-type platelets (data not shown). Western blot analyses of platelets from mice that are homozygous for the targeted allele revealed no peptides that react with the polyclonal antiTSP-1 antibody (Fig. 3). These results show that aberrant peptides are not derived from the targeted allele and that the mice lack TSP-1 protein.

Phenotype of TSP-1-deficient mice. Mice that were derived from two targeted ES cell clones were used throughout this study. The presence of pneumonia in TSP-1-deficient mice (see below) was confirmed with a third ES cell clone. In both the mixed and homogeneous genetic backgrounds, the TSP-1deficient mice exhibit a lordotic curvature of the spine (Fig. 4). The amount of curvature varies but is apparent from the day of birth in affected individuals. Some TSP-1-deficient mice appear to have a flattening of the posterior portion of the spine.

No abnormalities were observed in most of the major organ systems of TSP-1-deficient mice in the 129Sv genetic background. These analyses included the brain, heart, liver, aorta, kidney, stomach, spleen, and intestines (aorta, cerebellum, and
A

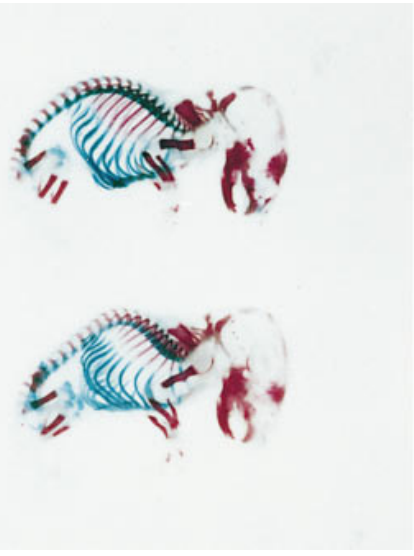

B

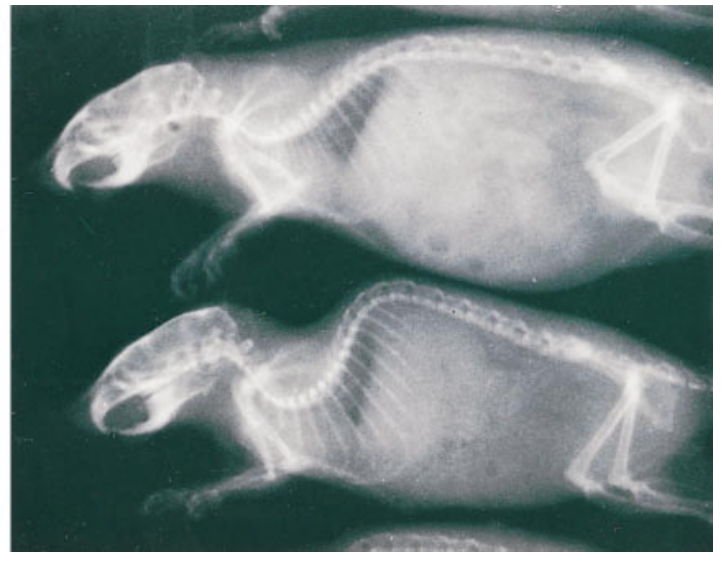

Figure 4. Lordotic curvature of the backbone in wild-type (top) or TSP-1-deficient mice (bottom). (A) The skeletons of newborn mice stained with alizarin red and Alcian blue. (B) X-ray pictures of adult mice. 

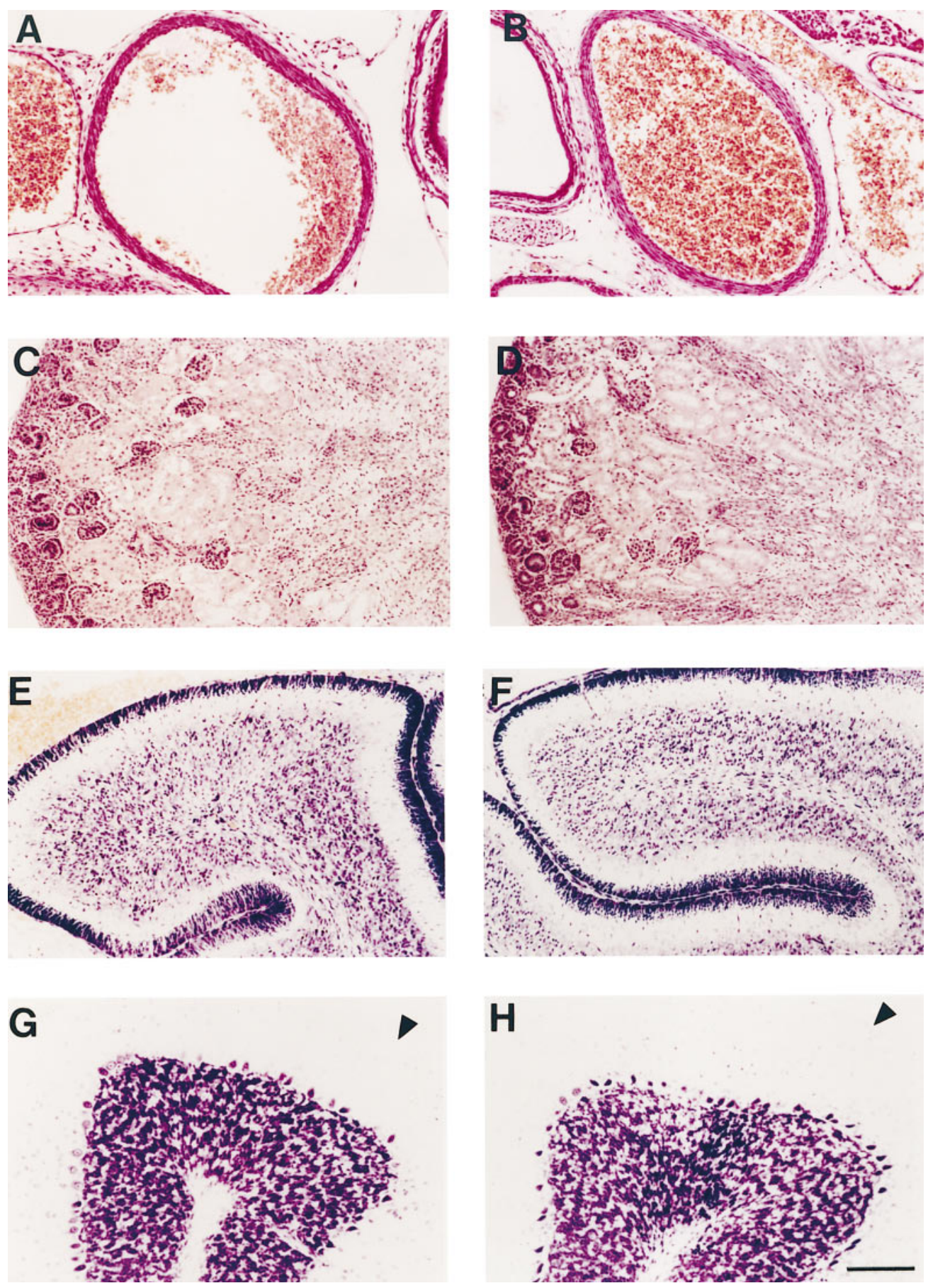

Figure 5. Histology of tissues from wild-type ( $A, C, E$, and $G$ ) and TSP-1-deficient mice $(B, D$, $F$, and $H)$. Transverse sections through the aorta $(A$ and $B)$ or kidney $(C$ and $D)$ of newborn mice stained with hematoxylin and eosin are shown. Sagittal sections of the cerebellum of 7-d-old $(E$ and $F)$ and 25-d-old $(G$ and $H)$ mice stained with cresyl fast violet (Nissl) stain. The arrow marks the surface of the cerebellum. Bar $=100 \mu \mathrm{m}$.

kidney sections are shown in Fig. 5). Since TSP-1 supports vascular smooth muscle cell proliferation in vitro, we examined the aorta for smooth muscle content $(14,15)$. As shown in Fig. 5, $A$ and $B$, the thickness and morphology of the smooth muscle cell layers around the aorta appear to be comparable in TSP-1-deficient and wild-type mice. Since TSP-1 has been reported to be involved in granule cell migration, the cellular architecture of the cerebellum was analyzed in detail (22). The structure of the cerebellum in TSP-1-deficient mice is similar to that of wild-type mice at birth and 7, 10, 15, 20, and $25 \mathrm{~d}$ after birth. Tissues from days 7 and 25 are shown in Fig. 5, $E-H$. Since TSP-1 can inhibit angiogenesis, we quantitated the num- ber of capillaries in the outer layer of the cortex of the brain (41). The number of capillaries in the TSP-1-deficient brains is equivalent to the number observed in wild-type brains, 1.5 and $25 \mathrm{~d}$ after birth (Table I).

RNase protection analysis was used to determine if TSP-2, -3 , and -4 are upregulated in TSP-1-deficient mice to compensate for the absence of TSP-1. The level of TSP-2, -3 , and -4 RNA was normalized to actin RNA levels in adult brain, heart, lung, and kidney as well as in the 2.5 -d-old pup. As summarized in Table II, the levels of TSP-2, -3 , and -4 in TSP-1deficient mice are not significantly different from those in the wild-type mice. The lung is the only tissue that expresses a 
Table I. Brain Capillary Counts

\begin{tabular}{lrr}
\hline & \multicolumn{2}{c}{ Genotype } \\
\cline { 2 - 3 } Age & \multicolumn{1}{c}{$+1+$} & \multicolumn{1}{c}{$-/-$} \\
\hline $1.5 \mathrm{~d}$ & $98.7 \pm 24.1(n=12)$ & $95.8 \pm 13.2(n=12)$ \\
$25 \mathrm{~d}$ & $104.7 \pm 12.7(n=12)$ & $109.3 \pm 12.6(n=12)$
\end{tabular}

level of TSP-3 that is significantly more than one standard deviation above the wild-type level. As described below, this difference probably results from epithelial cell hyperplasia rather than gene regulation.

Lung histopathology in TSP-1-deficient and wild-type mice. The lungs of the TSP-1-deficient mice develop normally and do not differ appreciably from those of wild-type mice at birth. The only notable phenotypic effect of the disrupted TSP-1 gene is the consistent appearance of acute and organizing bacterial pneumonia. By histopathological examination of lung sections from the mice, this phenotype arises between 1 and 4 mo of life in homozygous TSP-1-deficient mice. Representative sections are shown in Fig. 6. At $1 \mathrm{~d}$ old, there is no major difference in overall lung architecture or cytodifferentiation between TSP-1-deficient (Fig. $6 B$ ) and normal mice (Fig. $6 \mathrm{~A}$ ). By the age of $1 \mathrm{mo}$, the vast majority of wild-type mice retain normal lung histopathology (Fig. $6 C$ ). In contrast, seven out of nine 1-mo-old TSP-1-deficient mice demonstrate widespread patchy, acute, and chronic organizing pneumonia (Fig. $6 \mathrm{D}$ ). This is manifested as prominent neutrophilic infiltrates and edema involving the alveoli and perivascular connective tissue, but not the conducting airways. By the age of 4 mo, the differences between normal lung in wild-type mice (Fig. 6 E) and chronically injured lung in TSP-1-deficient mice (Fig. $6 F$ ) are increasingly apparent. Inflammatory infiltrates include both neutrophils and mononuclear cells, in varying proportions in different foci, consistent with multiple foci of pneumonia of different ages (Fig. $6 F$ ). There is also widespread disruption of lung architecture, with patchy fibrosis and airway epithelial cell hyperplasia, including the formation of inflammatory pseudopolyps projecting into some of the airway lumens (Fig. $6 \mathrm{~F}$ ). The disruption of normal architecture in these regions is more clearly demonstrated by histochemical staining for elastin (Fig. $6 \mathrm{H}$, black) and trichrome staining to highlight established fibrous connective tissue (Fig. $6 \mathrm{G}$, blue). All TSP-1-deficient mice $(n=12)$ between the ages of 2.5 and 7 mo had widespread patchy, acute, and chronic organizing pneumonia. Small foci of acute pneumonia were identified in 3 wild-type mice out of 13 examined at 1-7 mo of age.

To characterize further the nature of the epithelial cell hyperplasia occurring in TSP-1-deficient mice, immunohisto- chemical analyses were carried out for markers of three major epithelial cell lineages in the lung: CC10, the Clara cell secretory protein; SP-C, which is exclusively expressed by type II alveolar pneumocytes; and CGRP, a specific and sensitive marker of mature neuroendocrine cells in adult rodent lung. The results of these analyses are given in Fig. 7. Prominent hyperplasia of all three epithelial cell types is apparent in TSP-1deficient (Fig. 7, $B, D$, and $F$ ) as compared with wild-type mice (Fig. 7, $A, C$, and $E$ ). Clara cells lining the bronchioles are larger and more numerous in regions both involved and uninvolved by pneumonia. Clara cells in the lungs of TSP-1-deficient mice are stratified and frequently form papillary projections into the airway lumen (Fig. $7 B$ ), as compared with the single layer of small Clara cells in normal mice (Fig. $7 A$ ). Numerous SP-C-positive type II cells are identified in TSP-1-deficient mice (Fig. $7 \mathrm{D}$ ), especially in regions directly involved with organizing pneumonia, whereas only rare type II cells are apparent in wild-type mice as expected in normal adults (Fig. 7 $C)$. SP-A is also abundantly expressed in both Clara cells and type II cells in TSP-1-deficient and control mice (data not shown). TSP-1-deficient mice also demonstrate markedly increased numbers of CGRP-positive pulmonary neuroendocrine cells (Fig. $7 F$ ) as compared with normal mice (Fig. $7 E$ ), with more neuroendocrine cells per cluster and more clusters per unit length of bronchiolar epithelium. Similar to Clara cells, the volume of cytoplasm and nucleus in the neuroendocrine cells is increased, suggesting that these cells might be activated in the setting of acute and chronic lung injury. Hyperplastic Clara cells and neuroendocrine cells are apparent throughout the lungs of TSP-1-deficient mice, including otherwise normal regions uninvolved by acute and/or organizing pneumonia.

To determine possible inciting factors and cellular responses to tissue injury in TSP-1-deficient mice, Prussian blue histochemical staining was carried out to clarify whether chronic hemorrhage is a prominent feature of the lung injury occurring in TSP-1-deficient mice. Whereas wild-type mice have very few alveolar macrophages with or without heme iron deposition (Fig. $7 \mathrm{G}$ ), TSP-1-deficient mice demonstrate increased numbers of hemosiderin-laden alveolar macrophages by 1 mo of age (data not shown), and have abundant hemosiderin-laden macrophages throughout the lungs by $4 \mathrm{mo}$ of age (Fig. $7 \mathrm{H}$ ). Most of these hemosiderin-laden macrophages occur in regions of the lung uninvolved by pneumonia. Chronologically, the hemosiderin deposition appears to follow the pneumonia, suggesting that it is secondary to chronic tissue damage rather than being a cause of injury in itself. Tissue Gram stain demonstrates occasional gram-positive cocci, located both extracellularly in the alveolar spaces and within alveolar macrophages and neutrophils (data not shown). Lung cultures of both wild-type mice and TSP-1-deficient mice grew

Table II. mRNA Levels for Thrombospondins

\begin{tabular}{cccccc}
\hline & 2.5-d-old & Brain & Heart & Lung & Kidney \\
\hline TSP-2 & $0.99 \pm 0.21(3)$ & $1.32 \pm 0.59(6)$ & $0.83 \pm 0.23(6)$ & $1.34 \pm 0.61(8)$ & $1.07 \pm 0.30(3)$ \\
TSP-3 & $1.09 \pm 0.43(5)$ & $0.64 \pm 0.37(4)$ & $0.85 \pm 0.30(4)$ & $1.31 \pm 0.23(4)$ & $1.66 \pm 0.69(4)$ \\
TSP-4 & $1.02 \pm 0.12(3)$ & $1.19 \pm 0.13(3)$ & $0.67 \pm 0.20(3)$ & - & -
\end{tabular}

Data are expressed as fraction of wild-type levels after normalization against actin mRNA. 

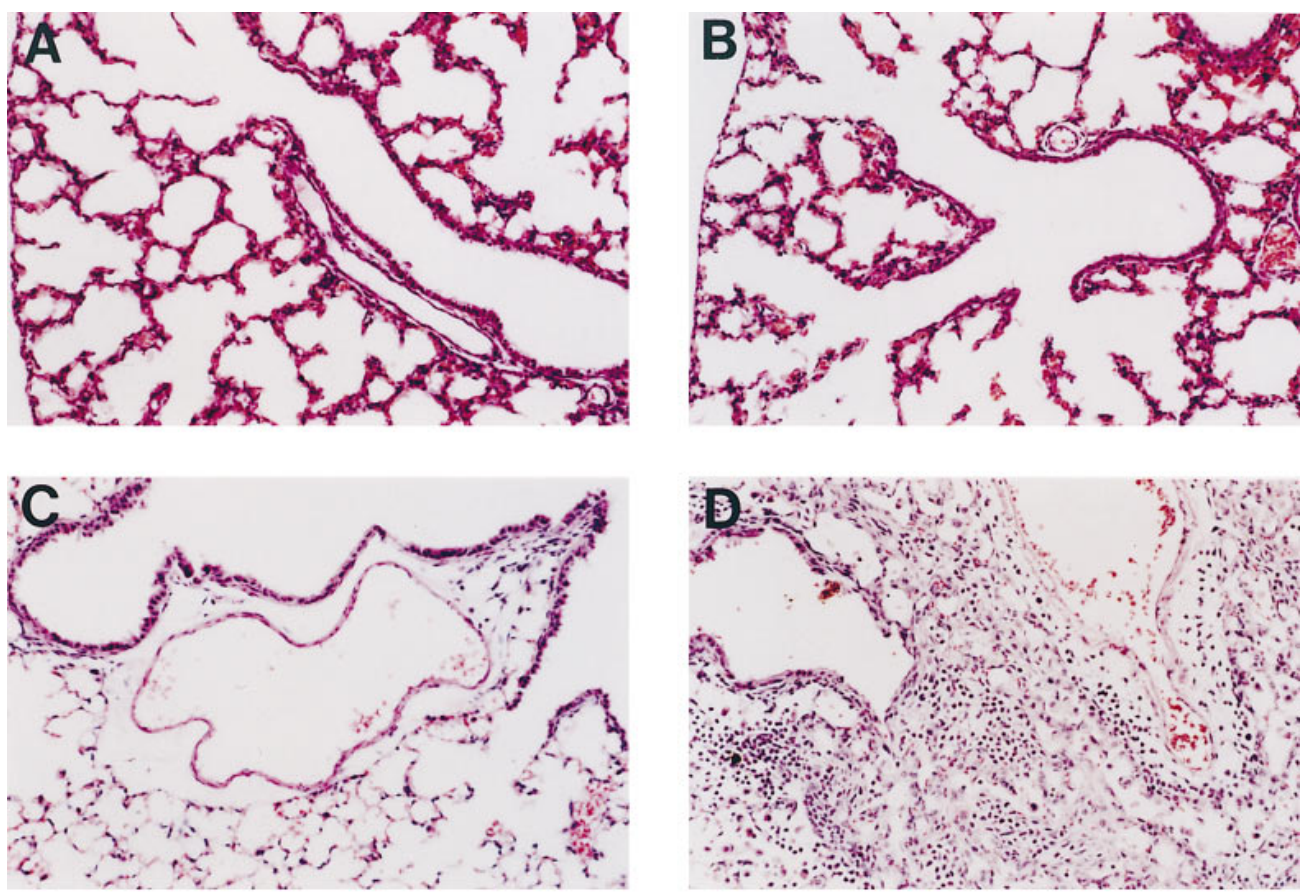

Figure 6. Histology of lung tissue from TSP-1-deficient and wild-type mice. Representative sections are shown from TSP-1deficient $(B, D$, and $F-H)$ and wild-type ( $A, C$, and $E$ ) mice. ( $A$ and $B)$ At $1 \mathrm{~d}$ old, there is no difference in lung architecture or cytodifferentiation between
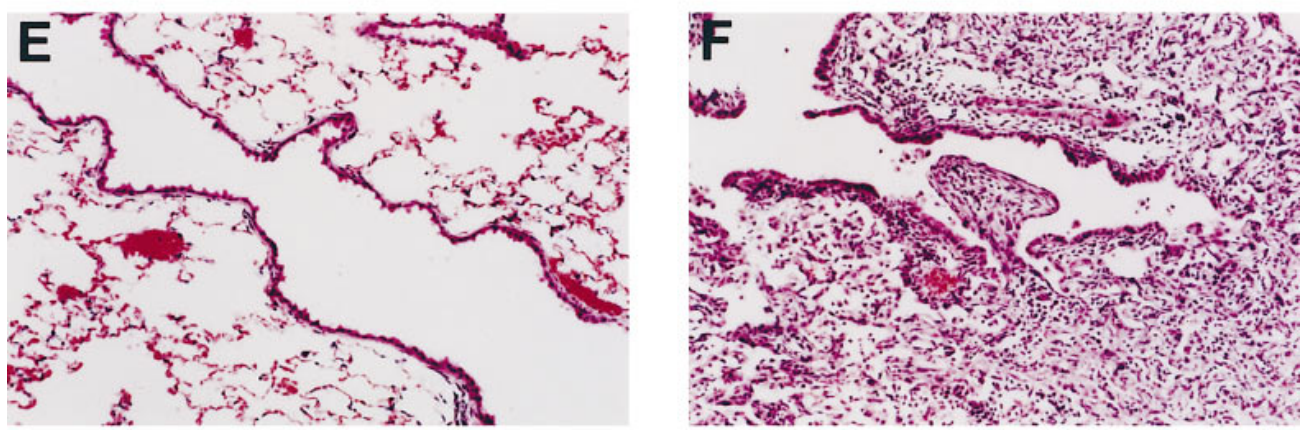

TSP-1-deficient mice $(B)$ and controls $(A)$. Tissue sections were stained with hematoxylin and eosin. ( $C$ and $D)$ At 1 mo old, there are prominent neutrophilic infiltrates with some mononuclear cell infiltrates and early organization in TSP-1deficient mice $(D)$ but not in most normal mice $(C)$ (hematoxylin and eosin). ( $E-H)$ At 4 mo of age, lungs of wild-type mice remain normal $(E)$, but there is variable architectural disruption
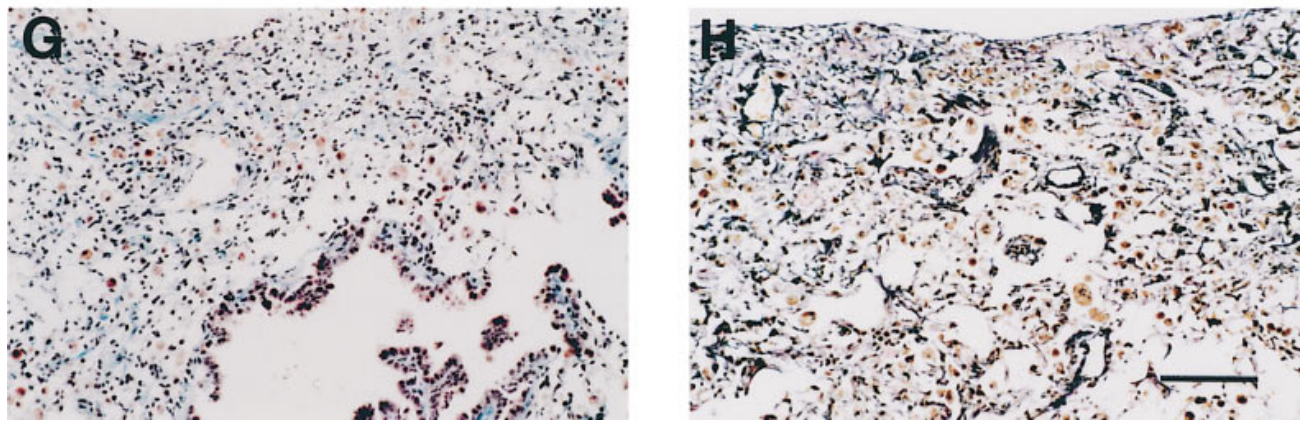
throughout the lungs of TSP-1deficient mice $(F-H)$ that is largely associated with scattered foci of acute and chronic organizing pneumonia ( $E$ and $F$, hematoxylin and eosin; $G$, trichrome stain; and $H$, elastin stain). Interstitial fibrous connective tissue was not observed with trichrome or elastin staining in wild-type mice (data not shown). Bar $=100 \mu \mathrm{m}$.

out the same spectrum of mixed bacterial flora: group D Streptococcus and Pasteurella pneumotropica.

Hematological characterization of TSP-1-deficient mice. White blood cell counts were performed on TSP-1-deficient mice in the homogenous 129Sv background. TSP-1-deficient mice exhibited a significant $(P \leq 0.0005)$ increase in total white blood cell counts (Table III). All subpopulations of white blood cells were elevated with the greatest percent increase occurring in those populations that are low in wild-type mice (eosinophils and monocytes). Platelet counts, hemoglo- bin levels, and hematocrits were equivalent in the normal and TSP-1-deficient mice (Table III).

Since TSP-1 has been reported to be involved in platelet aggregation and we observe diffuse alveolar hemorrhage, we compared the bleeding time and thrombin-induced aggregation in TSP-1-deficient and wild-type mice (42-46). The bleeding time of the TSP-1-deficient mice $(90.5 \pm 37.1 \mathrm{~s}, n=15)$ was comparable to that of the wild-type mice $(98.9 \pm 49.6 \mathrm{~s}, n=15)$. In addition, the aggregation of washed platelets in response to thrombin was equivalent (Fig. 8). 

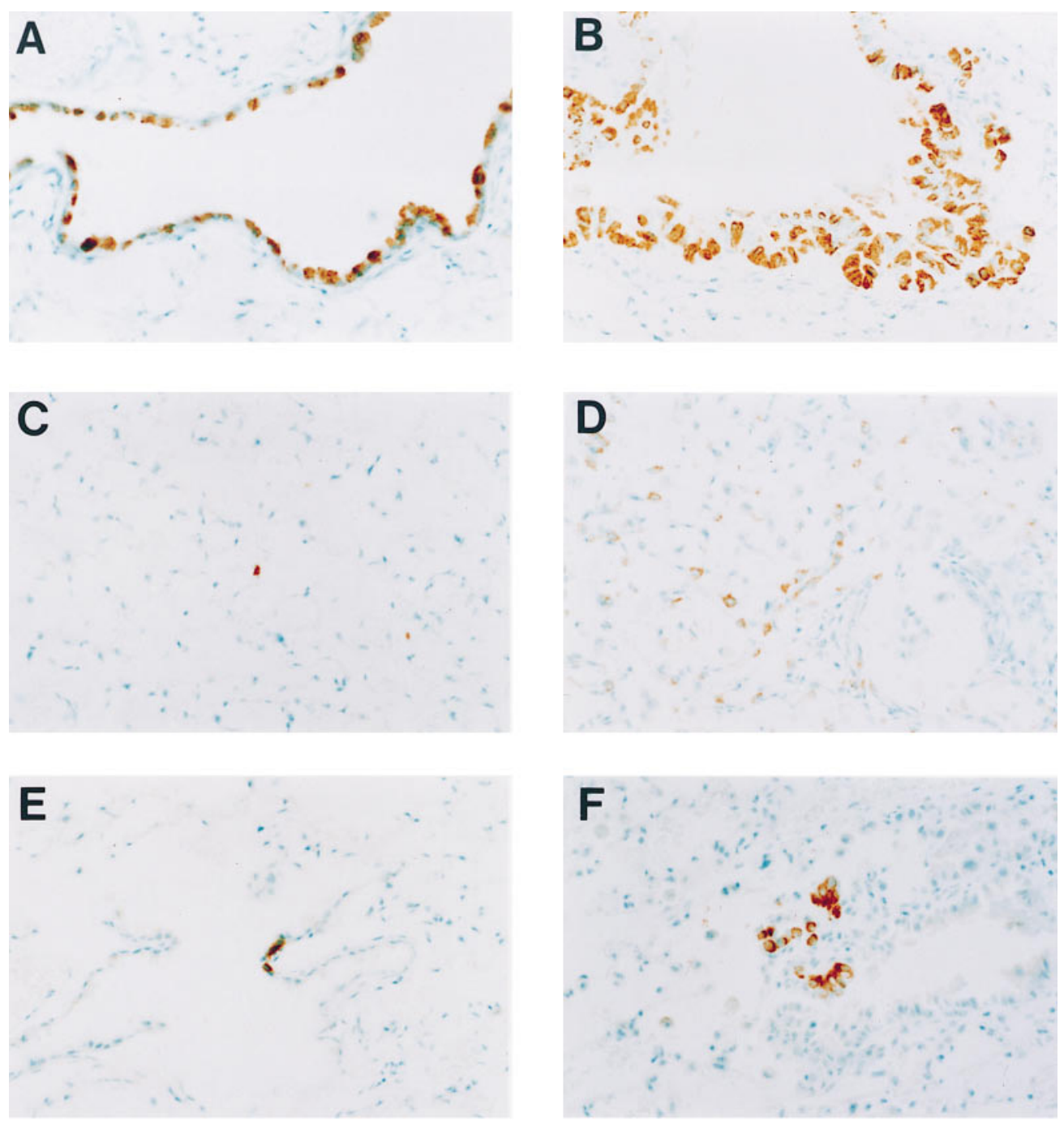

Figure 7. Histochemical analyses of lung epithelial cell differentiation and hemosiderin deposition in TSP-1-deficient and wild-type mice. Representative sections are shown from TSP-1deficient $(B, D, F$, and $H)$ and wild-type $(A, C, E$, and $G$ ) mice. ( $A$ and $B$ ) CC10 immunostaining for Clara cells in TSP-1-deficient mice $(B)$ and controls $(A)$ (methyl green counterstain). ( $C$ and $D$ ) SP-C immunostaining for type II pneumocytes in TSP-1deficient mice $(D)$ and controls $(C)$ (methyl green counterstain). ( $E$ and $F$ ) CGRP immunostaining for neuroendocrine
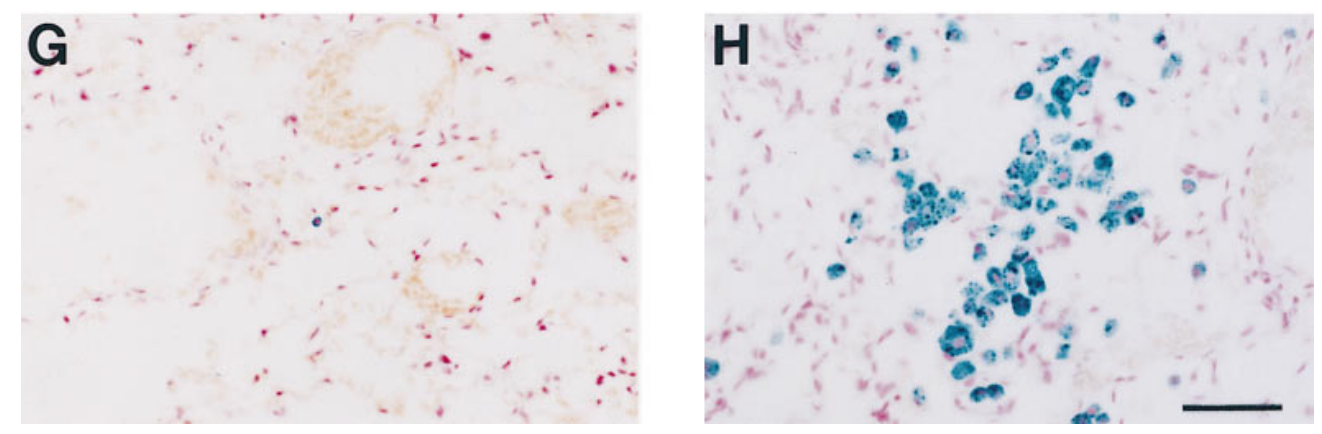
cells in TSP-1 null mice $(F)$ versus controls $(E)$ (methyl green counterstain). ( $G$ and $H$ ) Prussian blue iron staining demonstrates prominent hemosiderinladen alveolar macrophages in the lung parenchyma of TSP-1deficient mice $(H)$ but only infrequent hemosiderin-positive cells in age-matched controls $(G)$. Bar $=50 \mu \mathrm{m}$.

\section{Discussion}

TSP-1 has been reported to be involved in cell differentiation, migration, adhesion, and survival (for review see reference 1). In addition, it is widely expressed during murine development (19-21). These observations suggested that deletion of the TSP-1 gene might result in embryonic lethality. This is obviously not the case; TSP-1-deficient mice are viable and fertile. However, the decreased number of homozygous offspring in both the heterozygous and homozygous crosses suggests that there is an $\sim 20 \%$ decrease in the viability of the homozygous embryos or neonates. A much larger population of mice would need to be analyzed to determine precisely the magnitude and significance of the difference between the TSP-1-deficient and wild-type mice (47). In addition to an apparent decrease in viability, matings of the TSP-1-deficient mice also produce fewer litters. Whereas an average wild-type breeding pair produces a total of 45 offspring, an average breeding pair of TSP-1-deficient mice produces a total of 16 offspring over its lifetime. The decrease in viability and fecundity probably provide sufficient selective pressure to maintain the TSP-1 gene in the mouse genome. 
Table III. Blood Cell Counts

\begin{tabular}{lcc}
\hline & $+/+$ & $-/-$ \\
\hline Total white cell counts & $5316 \pm 1336(n=41)$ & $8519 \pm 3237(n=46)$ \\
Differential counts: & & \\
Total white cell counts & $4973 \pm 1249(n=16)$ & $8148 \pm 3954(n=16)$ \\
PMN & $871 \pm 380(17.5 \%)$ & $1009 \pm 528(12.4 \%)$ \\
Eosinophils & $156 \pm 111(3.1 \%)$ & $444 \pm 387(5.5 \%)$ \\
Lymphocytes & $3838 \pm 1119(77.2 \%)$ & $6399 \pm 3301(78.7 \%)$ \\
Monocytes & $105 \pm 96(2.1 \%)$ & $279 \pm 229(3.4 \%)$ \\
Platelet counts & $708 \pm 112 \times 10^{3}$ & $742 \pm 118 \times 10^{3}$ \\
& $(n=16)$ & $(n=21)$ \\
Red blood cell counts & $9.43 \pm 0.48 \times 10^{6}$ & $9.79 \pm 0.62 \times 10^{6}$ \\
& $(n=16)$ & $(n=21)$ \\
\hline
\end{tabular}

In vitro, vascular smooth muscle cell proliferation is inhibited by various monoclonal antibodies against TSP-1 (15). In addition, antibodies to TSP-1 inhibit granule cell migration in explant cultures of cerebellar cortex (22). By contrast, the aorta and cerebellum in TSP-1-deficient mice do not exhibit major defects. The lack of abnormalities in development of organs in which in vitro data predict an effect indicates that TSP-1 is not essential in vivo during the development of these organs. The knockout mouse data do not invalidate the in vitro data. Whereas antibody or peptide blocking studies ask if a protein is normally involved in a process, gene ablation studies ask if a protein is uniquely essential (48). In vivo, other matrix proteins may compensate for the absence of TSP-1 (49). This would require both proteins to be expressed in the same tissues. Whereas each thrombospondin has a unique expression pattern, most tissues do express more than one thrombospondin and multiple other matrix proteins. With the exception of fibronectin, knockouts of adhesive extracellular matrix glycoproteins have produced mice with surprisingly mild abnormalities (48).

The role of TSP-1 in platelet aggregation has been studied because TSP- 1 is a principal constituent of platelet $\alpha$-granules. Antibodies against TSP-1 inhibit adenosine diphosphate-, collagen-, and thrombin-induced platelet aggregation (42-46). Whereas Dixit et al. (43) observed inhibition of platelet aggregation induced by $0.5 \mathrm{U} / \mathrm{ml}$ of thrombin, Kao et al. (44) reported that anti-TSP-1 antibodies are inhibitory at lower doses of thrombin only $(0.02 \mathrm{U} / \mathrm{ml}$ for human platelets $)$ where the aggregation response is submaximal. We have tested the aggregation response of wild-type mouse platelets at varying thrombin concentrations to determine the appropriate concentration range. The aggregation response varies with mouse strain with platelets from $129 \mathrm{~Sv}$ mice being less responsive to thrombin than platelets from C57BL/6 mice (Lawler, J., unpublished data). In this study, wild-type and TSP-1-deficient platelets have equivalent aggregation responses. Since TSP-1 colocalizes with fibrinogen and $\alpha \mathrm{IIb} \beta 3$ on the surface of thrombin-treated platelets, antibodies to TSP-1 may inhibit platelet aggregation by steric hindrance of the formation of the fibrinogen- $\alpha \operatorname{IIb} \beta 3$ complex $(45,46)$. The normal level of platelet aggregation in TSP-1-deficient mice is consistent with the observation that these mice do not have bleeding diatheses and have normal bleeding times. Like platelet-derived growth factor or TGF- $\beta$, TSP-1 may be included in platelet $\alpha$-granules to facilitate tissue repair that occurs subsequent to thrombosis.
The most prominent defect in the TSP-1-deficient mice is in their lungs. The lungs of these mice exhibit acute and chronic inflammatory cell infiltrates. The stimulus for the influx of inflammatory cells is unknown at present. Factors that may contribute to the neutrophil and monocyte recruitment include $(a)$ aberrant production of stimulating or inhibitory cytokines; (b) abnormal production or degradation of extracellular matrix; $(c)$ defective phagocytosis; and $(d)$ defective opsonization of bacteria that are present and are nonpathogenic in the wild-type mice maintained in the same colony. The lesions in the TSP-1-deficient mice are persistent and progress toward increased fibroblastic and epithelial cell proliferation, matrix deposition, and diffuse alveolar hemorrhage. The increased white blood cell counts are likely to result from a chronic state of infection. A role for TSP-1 in inflammatory and possibly immune responses in the lung is consistent with the observation that TSP-1 is expressed during organizing pneumonia in humans (50). It is unlikely that secondary deficiencies of $\mathrm{CC} 10$ or SP-A protein expression contribute to the observed abnormalities because both of these antigens are present in TSP-1-deficient mice.
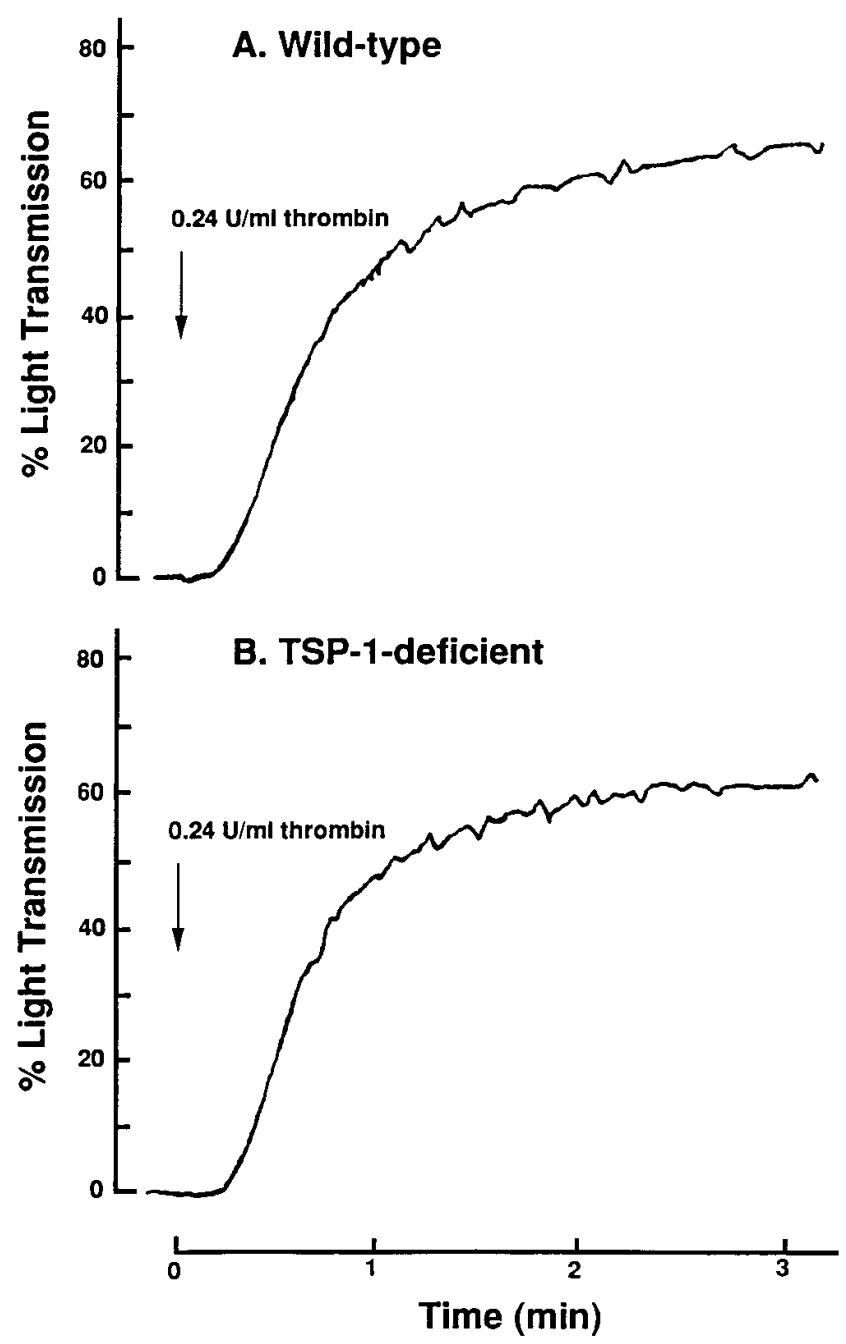

Figure 8 . Thrombin-induced platelet aggregation. Washed platelets from wild-type $(A)$ or TSP-1-deficient mice $(B)$ were treated with $0.24 \mathrm{U} / \mathrm{ml}$ of thrombin at $37^{\circ} \mathrm{C}$ with continuous stirring. 
Deficiencies in several functions of TSP-1 that have been identified in vitro may contribute to the lung pathology. TSP-1 reportedly activates TGF- $\beta$ (12). TGF- $\beta$ acts to suppress the immune system as evidenced by the fact that TGF- $\beta$-deficient mice die as a result of massive mononuclear inflammatory cell infiltrates in many organs (51-53). In the lung, TGF- $\beta$-deficient mice exhibit perivascular cuffing of lymphocytes, macrophages, and plasma cells, and interstitial pneumonia (51-53). In the absence of TSP-1, lesser amounts of active TGF- $\beta$ may be produced in the lung and an exaggerated inflammatory response may occur. The lesion may be specific to the lung because TSP-1 is normally expressed at high levels in the lung and because this organ is directly exposed to the external environment. Khalil and co-workers (Yehualaeshet, T., J.E. Murphy-Ullrich, R. Silverstein, J. Green-Johnson, S. Mai, and N. Khalil, manuscript submitted for publication) have found that TSP-1 is involved in activation of TGF- $\beta$ by alveolar macrophages. In response to bleomycin-induced pulmonary injury, active TGF- $\beta$ is produced by alveolar macrophages through a mechanism that involves TSP-1, CD36, and plasmin. Currently, we are performing a detailed histological comparison of 2-3-wk-old TSP-1- and TGF- $\beta$-deficient mice to determine if similar lung abnormalities are present (Crawford, S.E., V. Stellmach, J. Murphy-Ullrich, J. Lawler, G.P. Boivin, R.O. Hynes, and N. Bouck, unpublished data).

An aberrant inflammatory and/or immune response in the lungs of TSP-1-deficient mice could arise from defects in recruitment or clearance of neutrophils or monocytes. TSP-1 reportedly supports neutrophil adhesion and migration, and primes for generation of oxidants (54). TSP-1 also supports monocyte chemotaxis, haptotaxis, and diapedesis $(55,56)$. In addition, TSP-1 is reportedly involved in the uptake and clearance of apoptotic neutrophils and eosinophils by macrophages $(57,58)$. Uptake of apoptotic neutrophils by the TSP-1-dependent mechanism does not elicit a proinflammatory response (59). Thus, this mechanism of clearance might limit the extent of the inflammation. Whereas large numbers of neutrophils and macrophages accumulate in the lungs of TSP-1-deficient mice, we have not studied the kinetics of recruitment or clearance. A defect in the regulation of the uptake or clearance of inflammatory cells may result in the persistent pneumonia that is observed in the lungs of TSP-1-deficient mice.

Multilineage epithelial cell proliferation in the lungs of TSP-1-deficient mice may result from the state of chronic active injury with the production of cytokines and the potential decrease in the levels of active TGF- $\beta$. Clara cell differentiation can be induced by $\gamma$-interferon (60). Neuroendocrine cell differentiation can be triggered by fibronectin or by TNF- $\alpha$ (Haley, K.J., and M. Sunday, manuscript in preparation). In addition, activated TGF- $\beta$ has been shown to downregulate lung epithelial cell proliferation (61). Thus, increased epithelial cell proliferation may occur in the absence of TSP-1-dependent activation of TGF- $\beta$.

TSP-1 is expressed in response to injury in skin, muscle, kidney, and vascular tissue (62-68). In addition, TSP-1-deficient mice display aberrant cutaneous wound healing (69). Thus, TSP-1 may function as a repair protein and could augment the function of other matrix molecules. If this is the case, the effects of knocking out other thrombospondins, tenascin, vitronectin, or other matrix molecules could be more severe on a TSP-1 null background.

The data presented here implicate TSP-1 as a key mediator of pulmonary homeostasis probably through regulation of the inflammatory and/or immune systems. This regulation suggests that TSP-1 is important for limiting the extent and/or duration of inflammation during the host response to lung injury.

\section{Acknowledgments}

The authors wish to thank Kim Mercer, Denise Crowley, and Ramon Silva for technical assistance and Trisha Duquette for doing the differential white blood cell counts. Bill Atkinson, Rosemary Jones, John Godleski, Rod Bronson, Peter Hauschka, Susan Crawford, Nöel Bouck, and Chuck Dangler provided valuable assistance in preparing and analyzing the histological data. Expert secretarial support was provided by Joan Smith and Carol Foss.

This work is supported by grants HL-28749 (to J. Lawler), POI HL-41484 (to R.O. Hynes), HL-50045 (to M. Sunday), and HL-44984 (to M. Sunday) from the Heart, Lung, and Blood Institute of the National Institutes of Health. R.O. Hynes is a Howard Hughes Medical Institute Investigator.

\section{References}

1. Adams, J.C., R.P. Tucker, and J. Lawler. 1995. The thrombospondin gene family. R.G. Landis, Austin. 191 pp.

2. Bornstein, P. 1995. Diversity of function is inherent in matricellular proteins. An appraisal of TSP-1. J. Cell Biol. 130:503-506.

3. Adams, J.C., and J. Lawler. 1993. Diverse mechanisms for cell attachment to platelet thrombospondin. J. Cell Sci. 104:1061-1071.

4. Asch, A.S., I. Liu, F.M. Briccetti, J.W. Barnwell, F. Kwakye-Berko, A Dokun, J. Goldberger, and M. Pernambuco. 1993. Analysis of CD36 binding domains: ligand specificity controlled by dephosphorylation of an ectodomain. Science. 262:1436-1440.

5. DeFreitas, M.F., C.K. Yoshida, W.A. Frazier, D.L. Mendrick, R.M Kysta, and L. Reichardt. 1995. Identification of integrin $\alpha_{3} \beta_{1}$ as a neuronal thrombospondin receptor mediating neurite outgrowth. Neuron. 15:333-343.

6. Gao, A.-G., F.P. Lindberg, M.B. Finn, S.D. Blystone, E.J. Brown, and W.A. Frazier. 1996. Integrin-associated protein is a receptor for the C-terminal domain of thrombospondin. J. Biol. Chem. 271:21-24.

7. Lawler, J., R. Weinstein, and R.O. Hynes. 1988. Cell attachment to thrombospondin. The role of ARG-GLY-ASP, calcium and integrin receptors. J. Cell Biol. 107:2351-2361.

8. Yabkowitz, R., V.M. Dixit, N. Guo, D.D. Robert, and Y. Shimizu. 1993. Activated T-cell adhesion to thrombospondin is mediated by the $\alpha 4 \beta 1$ (VLA-4) and $\alpha 5 \beta 1$ integrins. J. Immunol. 151:149-158.

9. Harpel, P.C., R.L. Silverstein, R. Pannell, V. Gurewich, and R.L. Nachman. 1990. Thrombospondin forms complexes with single-chain and two-chain forms of urokinase. J. Biol. Chem. 265:11289-11294.

10. Mosher, D.F., T.M. Misenheimer, and J. Stenflo. 1992. Modulation of fibrinolysis by thrombospondin. Ann. NY Acad. Sci. 667:64-69.

11. Silverstein, R.L., L.L.K. Leung, and P.C. Harpel. 1985. Platelet thrombospondin forms a trimolecular complex with plasminogen and histidine-rich glycoprotein. J. Clin. Invest. 75:2065-2073.

12. Schultz-Cherry, S., S. Ribeiro, L. Gentry, and J.E. Murphy-Ullrich 1994. Thrombospondin binds and activates the small and large forms of latent transforming growth factor- $\beta$ in a chemically defined system. J. Biol. Chem. 269:26775-26782.

13. Bagavandoss, P., and J.W. Wilks. 1990. Specific inhibition of endothelial cell proliferation by thrombospondin. Biochem. Biophys. Res. Commun. 170: 867-872.

14. Majack, R.A., S.C. Cook, and P. Bornstein. 1986. Control of smooth muscle cell growth by components of the extracellular matrix: autocrine role for thrombospondin. Proc. Natl. Acad. Sci. USA. 83:9050-9054.

15. Majack, R.A., L.V. Goodman, and V.M. Dixit. 1988. Cell surface thrombospondin is functionally essential for vascular smooth muscle cell proliferation. J. Cell Biol. 106:415-422.

16. Taraboletti, G., D. Roberts, and L.A. Liotta. 1990. Platelet thrombospondin modulates endothelial cell adhesion, motility and growth, a potential angiogenesis regulatory factor. J. Cell Biol. 111:765-772.

17. Adams, J.C., and J. Lawler. 1994. Cell-type specific adhesive interactions of skeletal myoblasts with thrombospondin-1. Mol. Biol. Cell. 5:423-437.

18. Murphy-Ullrich, J.E., S. Gurusiddappa, and W.A. Frazier. 1993. Heparin-binding peptides from thrombospondin 1 and 2 contain focal adhesionlabilizing activity. J. Biol. Chem. 268:26784-26789.

19. Corless, C.L., A. Mendoza, T. Collins, and J. Lawler. 1992. Colocalization of thrombospondin and syndecan during murine development. Dev. Dyn. 193:346-358. 
20. Iruela-Arispe, M.L., D.J. Liska, E.H. Sage, and P. Bornstein. 1993. Differential expression of thrombospondin 1, 2 and 3 during murine development. Dev. Dyn. 197:40-56.

21. O'Shea, K.S., and V.M. Dixit. 1988. Unique distribution of the extracellular matrix component thrombospondin in the developing mouse embryo. $J$. Cell Biol. 107:2737-2748.

22. O'Shea, K.S., J.S.T. Rheinheimer, and V.M. Dixit. 1990. Deposition and role of thrombospondin in the histogenesis of the cerebellar cortex. J. Cell Biol. 110:1275-1283.

23. Tucker, R.P., C. Hagios, R. Chiquet-Ehrismann, and J. Lawler. 1997. In situ localization of TSP-1 and thrombospondin-3 transcripts in the avian embryo. Dev. Dyn. 208:326-337.

24. DiCesare, P.E., M. Morgelin, K. Mann, and M. Paulsson. 1994. Cartilage oligomeric matrix protein and TSP-1: purification from articular cartilage, electron microscopic structure, and chondrocyte binding. Eur. J. Biochem. 223:927-937.

25. Wight, T.N., G.J. Raugi, S.M. Mumby, and P. Bornstein. 1985. Light microscopic immunolocation of thrombospondin in human tissues. J. Histochem. Cytochem. 33:295-302.

26. Sage, H., F.M. Farin, G.E. Striker, and A.B. Fisher. 1983. Granular pneumocytes in primary culture secrete several major components of the extracellular matrix. Biochemistry. 22:2148-2155.

27. Lawler, J., M. Duquette, and P. Ferro. 1991. Characterization of the murine thrombospondin gene. Genomics. 11:587-600.

28. George, E.L., E.N. Georges-Labousse, R.S. Patel-King, H. Rayburn, and R.O. Hynes. 1993. Defects in mesoderm, neural tube and vascular development in mouse embryos lacking fibronectin. Development. 119:1079-1091.

29. Mansour, S.L., K.R. Thomas, and M.R. Capecchi. 1988. Disruption of proto-oncogene int-2 in mouse embryonic stem cells: a general strategy for targeting mutations in non-selectable genes. Nature. 336:348-352.

30. Doetschman, T.C., H. Eistetter, M. Katz, W. Schmidt, and R. Kemler. 1985. The in vitro development of blastocyst-derived embryonic stem cell lines: formation of visceral yolk sac, blood islands and myocardium. J. Embryol. Exp. Morph. 87:27-45.

31. Laird, P.W., A. Zijderveld, K. Linders, M.A. Rudnicki, R. Jaenisch, and A. Berns. 1991. Simplified mammalian DNA isolation procedure. Nucl. Acids Res. 19:4293.

32. Lawler, J., M. Duquette, C.A. Whittaker, J.C. Adams, K. McHenry, and D.W. DeSimone. 1993. Identification and characterization of thrombospondin-4, a new member of the thrombospondin gene family. J. Cell Biol. 120:1059-1067.

33. Maniatis, T., E.F. Fritsch, and J. Sambrook. 1982. Molecular Cloning: A Laboratory Manual. Cold Spring Harbor Laboratory, Cold Spring Harbor, NY. 382-389.

34. Dawson, A.B. 1926. A note on the staining of the skeleton of cleared specimens with alizarin Red S. Stain Technol. 1:123-145.

35. Vorbroker, D.K., S.A. Profitt, L.M. Nogee, and J.A. Whitsett. 1994. Aberrant processing of surfactant protein $\mathrm{C}$ in hereditary SP-B deficiency. Am. J. Physiol. 268:L647-L656.

36. Sunday, M.E., C.G. Willett, K. Patidar, and S.A. Graham. 1994. Modulation of oncogene and tumor suppressor gene expression in a hamster model of chronic lung injury with varying degrees of pulmonary neuroendocrine cell hyperplasia. Lab. Invest. 70:875-888.

37. Sunday, M.E., C.G. Willett, S.A. Graham, V.I.C. Oreffo, R.I. Linnoila, and H. Witschi. 1995. Histochemical characterization of non-neuroendocrine tumors and neuroendocrine cell hyperplasia induced in hamster lung by 4-(methylnitro-samino)-1-(3-pyridyl)-1-butanone with or without hyperoxia. Am. J. Pathol. 147:740-752.

38. Laemmli, U.K. 1970. Cleavage of structural proteins during the assembly of the head of bacteriophage $\mathrm{T}_{4}$. Nature. 227:680-685.

39. Lawler, J., L.H. Derick, J.E. Connolly, J.-H. Chen, and F.C. Chao. 1985. The structure of human platelet thrombospondin. J. Biol. Chem. 260:37623772.

40. Dejana, E., A. Callioni, A. Quintana, and G. De Gaetano. 1979. Bleeding time in laboratory animals. II. A comparison of different assay conditions in rats. Thromb. Res. 15:191-197.

41. Tolsma, S.S., O.V. Volpert, D.J. Good, W.A. Frazier, P.J. Polverini, and N. Bouck. 1993. Peptides derived from two separate domains of the matrix protein TSP-1 have anti-angiogenic activity. J. Cell Biol. 122:497-511.

42. Leung, L.L.K. 1984. Role of thrombospondin in platelet aggregation. J. Clin. Invest. 74:1764-1772.

43. Dixit, V.M., D.M. Haverstick, K.M. O'Rourke, S.W. Hennessy, G.A. Grant, S.A. Santoro, and W.A. Frazier. 1985. A monoclonal antibody against human thrombospondin inhibits platelet aggregation. Proc. Natl. Acad. Sci. USA. 82:3472-3476.

44. Kao, K.J., D.M. Shaut, and P.A. Klein. 1986. Functional involvement of thrombospondin in platelet aggregation induced by low versus high concentrations of thrombin. Thromb. Haemostasis. 55:136-142.
45. Asch, A.S., L.L.K. Leung, M.J. Polley, and R.L. Nachman. 1995. Platelet membrane topography: colocalization of thrombospondin and fibrinogen with glycoprotein IIb-IIIa complex. Blood. 66:926-934.

46. Legrand, C., V. Thibert, V. Dubernard, B. Begault, and J. Lawler. 1992. Molecular requirements for the interaction of thrombospondin with thrombinactivated human platelets: modulation of platelet interaction. Blood. 79:19952003.

47. Brookfield, J. 1992. Can genes be truly redundant? Curr. Biol. 2:553-554.

48. Hynes, R.O. 1996. Targeted mutations in cell adhesion genes: What have we learned from them? Dev. Biol. 180:402-412.

49. Rudnicki, M.A., T. Braun, S. Hinuma, and R. Jaenisch. 1992. Inactivation of MyoD in mice leads to upregulation of the myogenic HLH gene Mfy-5 and results in apparently normal muscle development. Cell. 71:383-390.

50. Kuhn, C., and R. Mason. 1995. Immunolocalization of SPARC, tenascin and thrombospondin in pulmonary fibrosis. Am. J. Pathol. 147:1759-1769.

51. Kulkarni, A.B., C.-G. Huh, D. Becker, A. Geiser, M. Lyght, K.C. Flanders, A.B. Roberts, M.B. Sporn, J.M. Ward, and S. Karlsson. 1993. Transforming growth factor beta-1 null mutation in mice causes excessive inflammatory response and early death. Proc. Natl. Acad. Sci. USA. 90:770-774.

52. Shull, M.M., I. Ormsby, A.B. Kier, S. Pawlowski, R.J. Diebold, M. Yin, R. Allen, C. Sidman, G. Proetzel, D. Calvin, N. Annunziata, and T. Doetschman. 1992 Targeted disruption of the mouse transforming growth factor- $\beta 1$ gene results in multifocal inflammatory disease. Nature. 359:693-699.

53. Boivin, G.P., B.A. O'Toole, I.E. Ormsby, R.J. Diebold, M.J. Eis, T. Doetschman, and A.B. Kier. 1995. Onset and progression of pathological lesions in transforming growth factor-ß1-deficient mice. Am. J. Pathol. 146:276288.

54. Mansfield, P.J., L.A. Boxer, and S.J. Suchard. 1990. Thrombospondin stimulates motility of human neutrophils. J. Cell Biol. 111:3077-3086.

55. Mansfield, P.J., and S.J. Suchard. 1994. Thrombospondin promotes chemotaxis and haptotaxis of human peripheral blood monocytes. J. Immunol. 153:4219-4229.

56. Huber, A.R., S. Ellis, K.J. Johnson, V.M. Dixit, and J. Varani. 1992. Monocyte diapedesis through an in vitro vessel wall construct: inhibition with monoclonal antibodies to thrombospondin. J. Leukocyte Biol. 52:524-528.

57. Savill, J., N. Hogg, Y. Ren, and C. Haslett. 1992. Thrombospondin cooperates with CD36 and the vitronectin receptor in macrophage of neutrophils undergoing apoptosis. J. Clin. Invest. 90:1513-1522.

58. Stern, M., J. Savill, and C. Haslett. 1996. Human monocyte-derived macrophage phagocytosis of senescent eosinophils undergoing apoptosis: mediation of $\alpha_{\mathrm{v}} \beta_{3} / \mathrm{CD} 36 /$ thrombospondin recognition mechanism and lack of phlogistic response. Am. J. Pathol. 149:911-921.

59. Hughes, J., Y. Liu, J.V. Damme, and J. Savill. 1997. Human glomerular mesangial cell phagocytosis of apoptotic neutrophils: mediation by a novel CD36-independent vitronectin receptor/thrombospondin recognition mechanism that is uncoupled from chemokine secretion. J. Immunol. 158:4389-4397.

60. Magdaleno, S.M., G.Y. Wang, K.J. Jackson, M.K. Ray, S. Welty, R.H. Costa, and F.J. Demayo. 1997. Interferon-gamma regulation of Clara cell gene expression, in vivo and in vitro. Am. J. Physiol. 16:L1142-L1151.

61. Jetten, A.M., J.E. Shirley, and G. Stoner. 1986. Regulation of proliferation of respiratory tract epithelial cells by TGF- $\beta$. Exp. Cell Res. 167:539-549.

62. Watkins, S.C., G.W. Lynch, L.P. Kane, and H.S. Slayter. 1990. Thrombospondin expression in traumatized skeletal muscle: correlation of appearance with post-trauma regeneration. Cell Tissue Res. 261:73-84.

63. DiPietro, L.A., N.N. Nissen, R.L. Gamelli, A.E. Koch, J.M. Pyle, and P.J. Polverini. 1996. TSP-1 synthesis and function in wound repair. Am. J. Pathol. 148:1851-1860.

64. Raugi, G.J., J.E. Olerud, and A.M. Gown. 1987. Thrombospondin in early human wound tissue. J. Invest. Dermatol. 89:551-554.

65. Raugi, G.J., J.S. Mullen, D.H. Bark, T. Okada, and M.R. Mayberg. 1990. Thrombospondin deposition in rat carotid artery injury. Am. J. Pathol. 137:179-185.

66. Reed, M.J., L. Iruela-Arispe, E.R. O'Brien, T. Truong, T. Label, P. Bornstein, and E.H. Sage. 1995. Expression of thrombospondins by endothelial cells: injury is correlated with TSP-1. Am. J. Pathol. 147:1068-1080.

67. McGregor, B., S. Colon, M. Mutin, E. Chignier, P. Zech, and J. McGregor. 1994. Thrombospondin in human glomerulopathies. Am. J. Pathol. 144: 1281-1287.

68. Thompson, E.M., J. Hughes, S. van Noorden, J. Sharpe, and J. Savill. 1996. Expression of the multifunctional extracellular matrix protein thrombospondin in crescentic glomerulonephritis. J. Pathol. 178:89-94.

69. Polverini, P.J., L.A. DiPietro, V.M. Dixit, R.O. Hynes, and J. Lawler. 1995. TSP-1 knockout mice showed delayed organization and prolonged neovascularization of skin wounds. FASEB (Fed. Am. Soc. Exp. Biol.) J. 9: A272. 